
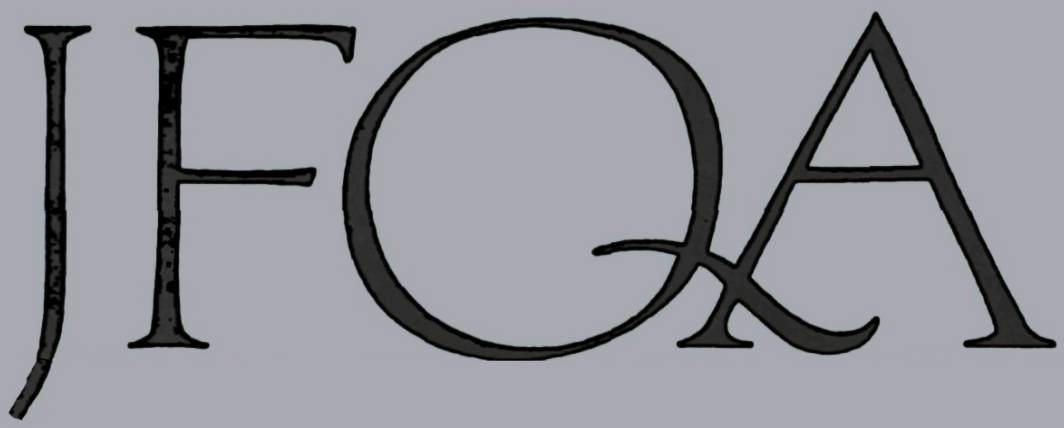

VOL. 33, NO. 1

MARCH 1998

MANAGING EDITORS

Stephen Brown

Jonathan Karpoff

Paul Malatesta

ASSOCLATE EDITORS

Michael Barclay

Sanjai Bhagat

Jennifer Conrad

Larry Dann

Philip Dybvig

Wayne Ferson

Michael Fishman

William Goetzmann

Richard Green

Mark Grinblatt

Lawrence Harris

Campbell Harvey

Robert Heinkel

John Hull

Robert Jarrow

Avraham Kamara

Steven Kaplan

Donald Keim

Robert Korajczyk

Josef Lakonishok

Ronald Masulis

John MoConnell

Robert McDonald

Wayne Mikkelson

Maureen O'Hara

Neil Pearson

Vance Roley

Eduardo Schwartz

Hans Stoll

Ralph Walkling

Ivo Welch

EDITOR

Martha Auvil
Permanent, Temporary, and Non-Fundamental Components of Stock Prices

Bong-Soo Lee

Pricing of Options on Commodity Futures with Stochastic Term Structures of Convenience Yields and Interest Rates Kristian R. Miltersen and Eduardo S. Schwartz

Valuation of Commodity Futures and Options under Stochastic Convenience Yields, Interest Rates, and Jump Diffusions in the Spot Jimmy E. Hilliard and Jorge Reis

Loan Commitments and the Debt Overhang Problem Christopher M. Snyder

A Strategic Analysis of Corners and Squeezes David J. Cooper and R. Glen Donaldson

Pricing Term Structure Risk in Futures Markets Frans A. de Roon. Theo E. Nijman, and Chris Veld 




JOURNAL OF FINANCIAL AND QUANTITATIVE ANALYSIS A PUBLICATION OF THE
UNIVERSITY OF WASHINGTON
SCHOOL OF BUSINESS ADMINISTRATION
IN COOPERATION WITH THE
NEW YORK UNIVERSITY
LEONARD N. STERN SCHOOL OF BUSINESS

VOL. 33, NO 1, MARCH 1998

Permanent. Temporary, and Non-Fundamental Components of Stock Prices

Bong-Soo Lee

Pricing of Options on Commodity Futures with Stochastic Term Structures of Convenience Yields and Interest Rates

Kristian R. Miltersen and Eduardo S. Schwartz

Valuation of Commodity Futures and Options under Stochastic

Convenience Yields, Interest Rates, and Jump Diffusions in the Spot

Jimmy E. Hilliard and Jorge Reis

Loan Commitments and the Debt Overhang Problem

Christopher M. Snyder

A Strategic Analysis of Corners and Squeezes

David J. Cooper and R. Glen Donaldson

Pricing Term Structure Risk in Futures Markets

Frans A. de Roon, Theo E. Nijman, and Chris Veld 
MANAGING EDITORS

$\begin{array}{lll}\text { Stephen Brown } & \text { Jonathan Karpoff } & \text { Paul Malatesta } \\ \text { New York University } & \text { University of Washington } & \text { University of Washington }\end{array}$

\section{ASSOCIATE EDITORS}

\section{Michael Barclay \\ University of Rochester \\ Sanjai Bhagat \\ University of Colorado \\ Jennifer Conrad \\ University of North Carolina \\ Larry Dann \\ University of Oregon \\ Philip Dybvig \\ Washington University \\ Wayne Ferson \\ University of Washington \\ Michael Fishman \\ Northwestern University \\ William Goetzmann \\ Yale University \\ Richard Green \\ Carnegie-Mellon University}

Mark Grinblatt

University of California, Los Angeles

Lawrence Harris

University of Southern California

Campbell Harvey

Duke University

Robert Heinkel

University of British Columbia

John Hull

University of Toronto

Robert Jarrow

Cornell University

Avraham Kamara

University of Washington

\author{
Steven Kaplan \\ University of Chicago \\ Donald Keim \\ University of Pennsylvania \\ Robert Korajczyk \\ Northwestern University \\ Josef Lakonishok \\ University of Illinois, \\ Urbana-Champaign \\ Ronald Masulis \\ Vanderbilt University \\ John McConnell \\ Purdue University \\ Robert McDonald \\ Northwestern University \\ Wayne Mikkelson \\ University of Oregon \\ Maureen O'Hara \\ Cornell University \\ Neil Pearson \\ University of Illinois, \\ Urbana-Champaign \\ Vance Roley \\ University of Washington
}

Eduardo Schwartz

University of California, Los Angeles

Hans Stoll

Vanderbilt University

Ralph Walkling

Ohio State University

Ivo Welch

University of California, Los Angeles

\section{STAFF}

Martha Auvil

Editor

Susan Huot

Nicolette Roberge

Office Manager

Gloria Young

Editorial Associates

POSTMASTER: Send address changes to Journal of Financial and Quantitative Analysis, School of Business Administration. University of Washington, $115 \mathrm{Lewis}$ Hall, Box 353200. Seattle, Washington 98195-3200.

Periodicals postage is paid at Seattle. Washington.

Copyright 1998, School of Business Administration. University of Washington. Journal of Financial and Quantitative Analysis-ISSN 0022-1090. 